\title{
The Old Poor Law and the Agricultural Labor Market in Southern England: An Empirical Analysis
}

GEORGE R. BOYER

\begin{abstract}
The paper examines the economic role played by poor relief in early nineteenthcentury England. A three-equation model is estimated to explain cross-parish variations in per capita relief expenditures, agricultural laborers' annual wage income, and unemployment rates. Relief expenditures are found to be related to crop mix, the political power of labor-hiring farmers, distance from London, and employment opportunities in cottage industry. The results strongly support the revisionist analysis of the Old Poor Law, and reject the analysis contained in the Report of the Royal Poor Law Commission.
\end{abstract}

$\mathrm{E}$ CONOMIC and social historians have expended a large amount of effort analyzing the administration of poor relief in England from the passage of Gilbert's Act in 1782 to the adoption of the Poor Law Amendment Act in 1834, and with good reason. During the period real per capita relief expenditures increased at a rate of nearly 1 percent per year. Several explanations have been offered for the rapid increase in expenditures: the disincentive effects of generous relief benefits, laborers' loss of land through enclosures and engrossment, the decline of employment opportunities in cottage industry for women and children, a reduction in wage rates for agricultural laborers.

To date, however, none of these explanations have been tested empirically. In view of the paucity of time-series data this is perhaps not surprising. But there is a gold mine of cross-sectional parish level information concerning the administration of poor relief, and agricultural labor markets in general, that has been underutilized. I refer to the Rural Queries, a questionnaire mailed to rural parishes throughout England in 1832 by the Royal Commission to Investigate the Poor Laws, and answered by approximately 1,100 parishes. The level of per capita relief expenditures differed significantly across counties, and across parishes within counties. Presumably the same explanations given for the long-term increase in relief expenditures can be used to account for

Journal of Economic History, Vol. XLVI, No. 1 (March 1986). (C) The Economic History Association. All rights reserved. ISSN 0022-0507.

The author is Assistant Professor of Labor Economics at New York State School of Industrial and Labor Relations, Cornell University, Ithaca, New York 14851-0952.

I wish to thank Ronald Ehrenberg, David Galenson, Donald McCloskey, Joel Mokyr, Jeffrey G. Williamson, and the participants at the Economic History workshops at Harvard University, Northwestern University, and the University of Chicago for helpful comments. The able research assistance of Joshua Schwarz is gratefully acknowledged. 
cross-parish variations in expenditures. By combining such information with occupational data from the 1831 Census it is possible to test most of the hypotheses explaining variations in relief expenditures. ${ }^{1}$

I provide here one such test. Data from a sample of southern parishes that responded to the Rural Queries are used to estimate a threeequation model to explain cross-parish variations in per capita relief expenditures, agricultural laborers' annual wage income, and the rate of unemployment. The results are used to evaluate explanations for the increase in expenditures on relief.

\section{EXPLANATIONS FOR THE LONG-TERM INCREASE AND REGIONAL VARIATIONS IN RELIEF EXPENDITURES}

Contemporary critics of the Old Poor Law focused on the effects of policies granting relief to able-bodied laborers outside of workhouses, but they did not explain the widespread adoption of such policies late in the eighteenth century. The most important contemporary analysis is the 1834 Report of the Royal Commission to Investigate the Poor Law. The Report concluded that the rapid increase in per capita relief expenditures during the first third of the nineteenth century was caused almost entirely by the widespread adoption of outdoor relief during the subsistence crises of 1795 and 1800. The system of outdoor relief, guaranteeing a minimum level of income, destroyed the motive for work. It created voluntary unemployment and lowered the productivity of workers who remained employed. Because most outdoor relief policies allowed employed laborers to apply for relief, they enabled labor-hiring farmers "to reduce wages to the minimum, or even below the minimum of what will support an unmarried man, and to throw upon others the payment of a part. . . of the wages actually received by their laborers." ${ }^{2}$ The long-term increase in relief expenditures was caused, therefore, by increased levels of voluntary unemployment and by the ability of farmers to substitute relief payments for wages as compensation for their workers.

The hypothesis did not originate with the Poor Law Commissioners; it was accepted by nearly every contemporary critic of the Old Poor Law. Much earlier Malthus had concluded that the Poor Laws dimin-

\footnotetext{
${ }^{1}$ To date the only attempt to determine the causes of cross-sectional variations in per capita relief expenditures during this period has been by G.S.L. Tucker, "The Old Poor Law Revisited," Explorations in Economic History, 12 (1975), pp. 233-52. Tucker's analysis is at the county level of aggregation, while poor relief was administered by the parish. Because relief administration and economic conditions were not uniform across parishes within a particular county, his analysis has serious shortcomings. Moreover, Tucker did not make use of the Rural Queries, and thus was unable to test several prominent hypotheses concerning the causes of cross-sectional variations in relief expenditures.

${ }^{2}$ Royal Commission to Investigate the Poor Laws, Report on the Administration and Practical Operation of the Poor Laws (London, 1834), pp. 68-70, 233-37, 59.
} 
ished workers' "incentives to sobriety and industry" and thus "create the poor which they maintain," and Ricardo wrote in 1817 that "whilst the present laws are in force, it is quite in the natural order of things that the fund for the maintenance of the poor should progressively increase till it has absorbed all the net revenue of the country." ${ }^{3}$ The critics of the administration of relief were unable to explain the regional variations in per capita relief expenditures. The commissioners concluded simply that "the abuses of the Poor Laws" were generally confined to the South of England.

Although the Poor Law Commission and most other contemporaries placed exclusive blame for increasing relief expenditures on the administration of relief, Frederick Eden and David Davies, the great social investigators of the 1790s, found evidence that the increase in relief expenditures was caused, at least in part, by important changes in the economic environment. Davies maintained that the real income of agricultural laborers had declined since 1750, as a result of "the general advance in the prices" of consumer goods, the decline in employment for women and children (due mainly to the collapse of cottage industry in the South), and the loss of cottage land through enclosures and engrossments. The decline in income from these sources forced parishes to increase their relief payments to poor workers. ${ }^{4}$ Eden's parishlevel investigation of The State of the Poor found employment opportunities and wage rates for women and children in cottage industry to be declining in several southern parishes. Moreover, Eden and Davies presented evidence of a negative correlation between earnings in cottage industry and poor relief expenditures. ${ }^{5}$

Eden and Davies also believed that granting allotments of land to poor laborers would significantly reduce their dependence on poor relief. Many others shared this belief. Barnett has determined that 184 pamphlets proposing allotment schemes were published between 1795 and $1835 .{ }^{6}$ The most vocal advocate of allotments was Arthur Young, who maintained that "the possession of a cottage and about an acre of land, ... if they do not keep the proprietor in every case from the parish, yet [they] very materially lessen the burden [of poor relief] in all."

${ }^{3}$ T. R. Malthus, An Essay on the Principle of Population (1st ed., 1798; reprint, New York, 1970), pp. 98, 97; D. Ricardo, The Principles of Political Economy and Taxation (1817; reprint, London, 1912), p. 61.

${ }^{4}$ David Davies, The Case of Labourers in Husbandry (Bath, 1795), p. 57.

${ }^{5}$ Frederic Morton Eden, The State of the Poor, 3 vols. (1797; reprint, London, 1966), vol. 2, pp. 2, 471, 687; vol. 3: p. 796. Davies, The Case of Labourers, pp. 84-86.

${ }^{6}$ Eden, State, vol. 1, pp. xx; Davies, The Case of Labourers, pp. 102-3; D. C. Barnett, "Allotments and the Problem of Rural Poverty, 1780-1840," in E. L. Jones and G. E. Mingay, eds., Land, Labour and Population in the Industrial Revolution (New York, 1968), p. 175.

${ }^{7}$ Arthur Young, Inquiry into the Propriety of Applying Wastes to the Better Maintenance and Support of the Poor (London, 1801), p. 509. On the other hand, Malthus argued that the ready availability of allotments "would be incomparably more powerful in encouraging a population 
Analysts of the Old Poor Law gave four reasons for the rapid increase in relief expenditures from 1780 to 1834 . Virtually every analyst claimed that the use of outdoor relief caused a reduction in labor supply, and hence an increased demand for relief. ${ }^{8}$ There was also general agreement that relief expenditures increased in response to declining wage rates, although there was some debate over the cause of declining wages. The Poor Law Commission and most others argued that after the adoption of outdoor relief the farmers lowered wages. ${ }^{9}$ Davies, however, claimed that the decline in real wages began decades before the widespread adoption of outdoor relief. Davies and Eden presented evidence that relief expenditures tended to be relatively low in areas where women and children were employed in cottage industry. Finally, many maintained that parishes where laborers were granted allotments of land tended to have relatively low poor rates.

Karl Polanyi in 1944 was the first person to present an alternative theory. ${ }^{10}$ While he accepted that increased relief expenditures were in part due to the loss of land by enclosure and to labor supply disincentives, Polanyi maintained that outdoor relief was a response by the countryside to the increased demand for labor in the city. Agriculture could not compete with urban wage rates by the late eighteenth century. In order to "prevent the draining off of rural labor," parishes adopted outdoor relief policies, which raised the income of agricultural laborers "without overburdening the farmer." Polanyi saw outdoor relief as part of a relatively inexpensive method for farmers to secure "an adequate reserve of labor" for peak seasons, because it enabled them to pass some of their labor costs onto the "rural middle class." Farmers

beyond the demand for labor than our present poor-laws." T. R. Malthus, A Letter to Samuel Whitbread . . . on His Proposed Bill for the Amendment of the Poor Laws (1807), 2nd ed., reprinted in The Pamphlets of Thomas Robert Malthus (New York, 1970), p. 396.

${ }^{8}$ For example, Eden concluded that the existing system of poor relief was "the parent of idleness and improvidence," and thus had "a tendency to increase the number of those wanting relief" (State of the Poor, pp. 481, 450).

${ }^{9}$ Malthus wrote that "it would appear from the different prices of labour in different parishes, and the different proportions of population relieved, that the farmers, although they bear themselves a large proportion of the assessments, have already learned in some places to prefer low wages and high rates, to low rates and high wages" (A Letter, p. 49).

${ }^{10}$ Two major interpretive studies of the Old Poor Law were published between the 1834 Poor Law Report and Karl Polanyi's The Great Transformation (New York, 1944)—namely John Hammond and Barbara Hammond's The Village Labourer, 1760-1832 (1911; reprint, New York, 1967), and Sidney Webb and Beatrice Webb's English Local Government: English Poor Law History: The Old Poor Law (London, 1927). While these two works are extremely important in the historiography of the Old Poor Law, they added little to the list of determinants of increased relief expenditures. The Hammonds maintained that the rapid increase in relief expenditures at the end of the eighteenth century was caused by the enclosure movement, which robbed laborers of their land, and by a simultaneous decline in real wage rates (pp. 106, 111). The Webbs' explanation was essentially the same (pp. 419-21). Both the Hammonds and the Webbs accepted the traditional hypothesis that outdoor relief policies caused "the destruction of all motives for effort and ambition" and hence that the continued increase in relief expenditures up to 1834 was due, in part, to the manner in which relief was administered (Hammond and Hammond, pp. 225, 231; Webb and Webb, pp. 172, 191, 194). 
preferred outdoor relief to allotments of land because allotments made workers too independent. For all this, however, Polanyi ignored the evidence of regional variations, maintaining that outdoor relief "became the law of the land over most of the countryside." ${ }^{11}$

Mark Blaug's 1963 paper, "The Myth of the Old Poor Law and the Making of the New," marked the beginning of a revisionist analysis of outdoor relief. Blaug maintained that outdoor relief did not appreciably reduce labor supply: the scale at which relief was given was so low that it could not have been "an attractive alternative to gainful employment." Rural parishes adopted outdoor relief policies in the 1790s in order to supplement wage rates that were precariously close to subsistence. By repairing "nutritional deficiencies," outdoor relief might in fact have increased labor productivity and hence caused an increase in wage rates. ${ }^{12}$ Blaug turned the conventional hypothesis completely on its head.

Blaug provided an explanation for the regional variations in per capita relief expenditures. Relief expenditures were relatively high in the South and East, first, because seasonality in the demand for agricultural labor was especially pronounced in grain production, and the Southeast was the major grain-producing region. Second, fixed-income annual labor contracts were common in the North, while in the South labor was hired by the week or even by the day. Third, southern rural areas suffered from "disguised unemployment" caused by the decline of cottage industry after 1800 and the "relative immobility of rural labor." 13

Most studies of the Old Poor Law published since 1963 have offered support for Blaug's conclusion. Taylor and Baugh maintained that since rural parishes were "generally small enough to apply any relief system with discretion," the disincentive effects of outdoor relief must have been small. ${ }^{14}$ Digby expanded on Blaug's contention that relief expenditures were positively correlated with the extent of seasonality in labor demand. She found that labor-hiring farmers dominated parish government in rural Norfolk, and that they responded to the seasonal nature of grain production by "exploiting their position as poor law administrators to pursue a policy with an economical alteration of poor relief and independent income for the labourer." 15

\footnotetext{
${ }^{11}$ Polanyi, Great Transformation, pp. 94, 297-99, 78.

${ }^{12}$ Mark Blaug, "The Myth of the Old Poor Law and the Making of the New," this JOURNAL, 23 (1963), pp. 151-84, especially 161-62, 154-55.

${ }^{13}$ Ibid., pp. 170-72.

${ }^{14}$ J. S. Taylor, "The Mythology of the Old Poor Law," this JOURNAL, 29 (1969), pp. 292-97, especially p. 295; Daniel A. Baugh, "The Cost of Poor Relief in South-East England, 1790-1834," Economic History Review, 2nd ser., 28 (1975), pp. 50-68, especially p. 61.

${ }^{15}$ Anne Digby, "The Labour Market and the Continuity of Social Policy After 1834: The Case of the Eastern Counties," Economic History Review, 2nd ser., 28 (1975), pp. 69-83, and Pauper Palaces (London, 1978), p. 105.
} 
McCloskey disagreed with one aspect of Blaug's analysis. He argued that outdoor relief was generally administered as an income subsidy "with a 100 percent marginal rate of tax on earned income below the minimum," and therefore must have produced serious work disincentives. He went on to note, however, that the reduction in labor supply resulting from outdoor relief policies would have led to an increase in wage rates, so long as outdoor relief did not shift the demand curve for agricultural labor. Thus, McCloskey concluded that the conventional hypothesis that outdoor relief reduced both the supply of labor and wage rates could not be correct. ${ }^{16}$

In a recent paper I have argued, as Polanyi did, that the major function of outdoor relief was to provide unemployment benefits for seasonally unemployed agricultural laborers. During the last two or three decades of the eighteenth century the decline of cottage industry, and the loss of land from enclosure and engrossment, created a class of rural laborers whose only source of income was wage labor in agriculture. In order to maintain the laborer's income at a subsistence level, farmers anxious to secure an adequate peak season labor force had to either raise agricultural wage rates or agree to grant poor relief to workers not needed during the winter months. ${ }^{17} \mathrm{I}$ argue, following Digby, that labor-hiring farmers were able to make this choice because they dominated the administrative affairs of the parishes.

I developed a simple model to compare alternative labor contracts. Labor-hiring farmers chose the wage rate, the slack season employment levels, and the weekly relief benefits for unemployed workers so as to maximize their profits subject to the constraint that any contract offered to workers had to yield an expected utility large enough to keep them from migrating to urban industrial areas. Contracts containing outdoor relief and layoffs dominated alternative contracts in areas where the demand for labor fluctuated sharply over the crop cycle; year-long wage contracts, by contrast, dominated in areas where the demand for labor remained steady throughout the year. ${ }^{18}$ Per capita relief expenditures would therefore be higher in grain-producing areas than in pasture farming areas, as they actually were. Moreover, the value of the compensation package, in terms of utility, that labor-hiring farmers had to offer in order to retain their workers was found to be negatively related to the cost of migrating from the parish to an urban industrial area. Assuming that cost of migration can be proxied by distance, wage rates or relief expenditures would have been lower the further a parish was from an urban labor market.

Employment opportunities for women and children in cottage indus-

\footnotetext{
${ }^{16}$ Donald McCloskey, "New Perspectives on the Old Poor Law," Explorations in Economic History, 10 (1973), pp. 419-36, especially p. 427.

${ }^{17}$ G. R. Boyer, "An Economic Role of the English Poor Law circa 1780-1834," Explorations in Economic History, 22 (1985), pp. 129-67, especially pp. 154-56.

${ }^{18}$ Ibid., pp. 156-60.
} 
try, or allotments of land, reduced the value of the implicit contract that farmers had to offer their workers. In response, poor relief expenditures might have declined, as Davies, Eden, and Young maintained. Yet farmers might have responded to such advantages by cutting wage rates for adult males. The small size of rural parishes suggests that it should not have been difficult for farmers to agree to do so. ${ }^{19}$

Of course, the extent to which farmers were able to respond to the existence of allotments or cottage industry by cutting wages rather than relief expenditures depended on the extent of their political power. Because this varied across parishes, there is no reason to believe that all parishes reacted in the same way to, say, the existence of cottage industry. Rather, I predict that labor-hiring farmers were more likely to reduce wage rates the more dominant they were in parish politics.

This summary of the literature on the economic role of the Old Poor Law has revealed several hypotheses concerning the causes of the rapid increase in relief expenditures from 1780 to 1834, and of regional variations in relief expenditures. Unfortunately the lack of time-series data makes it impossible to directly test the hypotheses concerning the long-term increase in relief expenditures. Most of the hypotheses can be tested indirectly, however, by a cross-sectional regression to explain variations in relief expenditures across parishes. For instance, if per capita relief expenditures were indeed negatively correlated with employment opportunities for women and children in cottage industry, it should be the case that at any point in time parishes with employment opportunities in cottage industry had lower per capita relief expenditures than parishes without cottage industry, other things equal. The hypotheses suggest that a single equation model would be inadequate to explain cross-parish variations in relief expenditures. Wage rates and unemployment rates determined relief expenditures, but relief expenditures lowered wage rates and increased unemployment rates.

\section{DATA}

The major data source used is the returns to the Rural Queries, an "elaborate" questionnaire distributed among rural parishes in the summer of 1832 by the Royal Poor Law Commission, and printed as Appendix B of the 1834 Poor Law Report. ${ }^{20}$ The Rural Queries

\footnotetext{
${ }^{19}$ For the sample of southern agricultural parishes used in the empirical analysis here, the average number of labor-hiring farmers per parish was 16 in 1831. There is no reason to believe that farmers would not have been eager to form a cartel to reduce wages rather than relief expenditures, since the method for financing poor relief ensured that all labor-hiring farmers would benefit from such a policy. Note that I am assuming that workers made decisions concerning migration based on their total compensation package rather than simply on their wage income in agriculture. In other words, I claim that it was not necessary to pay workers their marginal product in wages. It follows that a worker receiving poor relief should be indifferent between a reduction in wage income or in relief benefits.

${ }^{20}$ Parliamentary Papers, Report From His Majesty's Commissioners for Inquiry into the Administration and Practical Operation of the Poor Laws. Appendix Bl, Answers to Rural Queries (1834), vols. 30-34.
} 
contained 58 questions relating to the administration of poor relief, wage rates and employment opportunities for adult males, females, and children, seasonal levels of unemployment, the existence of cottage gardens and allotments for laborers, and the productivity of the labor force. It is not clear how many parishes received the questionnaire, but approximately 1,100 responses were returned, about 10 percent of the rural parishes in England.

The returns have never been fully utilized. Historians of the Old Poor Law have used them almost exclusively as a source of critical comment from local officials concerning the bad effects of outdoor relief. The reason for the neglect is the "unmanageable nature" of the data, which filled five folio volumes of Parliamentary Papers, each about a thousand pages in length. The Poor Law Commission itself was overwhelmed by the returns. The first and only attempt to analyze the returns was Blaug's, which tabulated at the county level the answers to questions dealing with various policies. ${ }^{21}$ Though providing important information concerning differences in the administration of outdoor relief across counties, the tabulation does not pretend to be a thorough statistical analysis.

I drew a sample of 329 parishes from the 21 counties lying south of a line between the Severn and the Wash. ${ }^{22}$ Outdoor relief was used most extensively in the South, and the Poor Law Commission and most historians have focused their analyses on southern counties. And there are reasons to believe that the responses of many northern parishes are not reliable. The Rural Queries were drawn up with southern agricultural parishes in mind, though mailed to parishes throughout England. Many of the northern parishes that responded were close to industrial cities and contained large numbers of handloom weavers and other nonagricultural laborers. They appear to have responded to questions concerning agricultural laborers with information on the poorest laborers in their parish, generally handloom weavers.

There are several problems associated with using the returns. First, the poor wording of some of the questions led to vague and sometimes uninterpretable responses. This is especially unfortunate in the case of Question 23, which asks: "What number of individuals received relief last week, not being in the workhouse?" Parishes answered this question in several ways. In rare cases the answer is stated in the form: "We have X number of men, women, and children on relief." The usual response simply states the number of recipients, without stating explicitly what the number entails. It is not possible to tell whether the answer

\footnotetext{
${ }^{21}$ Mark Blaug, "The Poor Law Report Reexamined," this JOURNAL, 24 (1964), pp. 229-45.

${ }^{22}$ The sample of 329 parishes was chosen from the 735 responses to the Rural Queries by southern parishes, on the basis of the completeness of their returns. All parishes that responded to each of a selected subset of questions deemed necessary for the statistical analysis were included in the sample.
} 
relates to the number of able-bodied heads of households on relief, the number of able-bodied heads and their wives and children, or the number of able-bodied heads, widows, old people, and infirm receiving outdoor relief. Equally seriously, because the parishes returned the Queries over a four-month period, from September 1832 to January 1833 , it is never clear when in the seasonal cycle the parish responded. The only reliable measure of relief expenditures available at the parish level is expenditures per capita. Although the variable fails to distinguish between incidence and generosity it has been used by virtually all students of the matter as a proxy for either or both.

The vagueness of parish responses to other questions made it possible to categorize their answers only as "yes" or "no." For instance, Question 20 asked: "Whether any land let to labourers; if so, the quantity to each, and at what rent?" A large number of parishes responded that laborers rented allotments but did not give the size of the allotments, the rent paid, or the size of the parish rent subsidy, if any. It was therefore possible only to determine the presence or absence of rented allotments. Similar responses were obtained from questions dealing with the use of allowances in aid of wages, child allowances, labor rates, and roundsmen systems, and the existence of cottage industry. The information from such questions could be introduced into the regression analysis only in the form of yes/no variables.

It was necessary to construct estimates of annual earnings when parishes reported wages but not earnings. For each county the relationship between wage rates and annual earnings was determined for parishes that returned both. This information was then used to estimate annual earnings in those parishes that reported only wage rates. A detailed description of how the earnings estimates were constructed is given in the Appendix.

The other major source of data was the 1831 Census, in particular the occupational enumeration. ${ }^{23}$ The Census reported the number of males 20 years of age and older for each parish, and the number belonging to each of nine occupational categories. I used five of the categories in constructing variables: farmers employing laborers, farmers not employing laborers (that is, family farmers), laborers employed in agriculture, persons employed in handicrafts and retail trade, and nonagricultural laborers. These data were used to estimate unemployment rates, specialization in agriculture, and the proportion of parish taxpayers who were labor-hiring farmers.

County averages for some of the variables included in the regression analysis are given in Table 1 . The extent of cottage industry and allotments varied enormously across counties. Cottage industry was prominent in the midland counties of Bedford, Buckingham, Northamp- 
TABLE 1

COUNTY AVERAGES: SELECTED VARIABLES

\begin{tabular}{|c|c|c|c|c|c|c|c|c|c|}
\hline & \multirow{2}{*}{$\begin{array}{c}\text { Per Capita } \\
\text { Relief } \\
\text { Expenditures, } \\
1831 \text { (s.,d.) }\end{array}$} & \multirow{2}{*}{$\begin{array}{c}\text { Average } \\
\text { Annual } \\
\text { Unemployment } \\
\text { Rate }\end{array}$} & \multirow{2}{*}{$\begin{array}{c}\text { Average } \\
\text { Summer } \\
\text { Unemployment } \\
\text { Rate }\end{array}$} & \multirow{2}{*}{$\begin{array}{c}\text { Average } \\
\text { Winter } \\
\text { Unemployment } \\
\text { Rate }\end{array}$} & \multicolumn{2}{|c|}{ Agricultural Laborers } & \multicolumn{2}{|c|}{ Percent of Parishes } & \multirow{2}{*}{$\begin{array}{c}\text { Percent of } \\
\text { Agricultural } \\
\text { Land in Grain } \\
\text { Production }\end{array}$} \\
\hline & & & & & $\begin{array}{l}\text { Reported } \\
\text { Annual } \\
\text { Income }\end{array}$ & $\begin{array}{c}\text { Expected } \\
\text { Annual } \\
\text { Income }\end{array}$ & $\begin{array}{c}\text { With } \\
\text { Cottage } \\
\text { Industry }\end{array}$ & $\begin{array}{c}\text { Granting } \\
\text { Allotments }\end{array}$ & \\
\hline Sussex & 19.4 & $9.6 \%$ & $4.8 \%$ & $13.8 \%$ & 31.78 & 28.73 & $1.2 \%$ & $38.1 \%$ & 36.0 \\
\hline Buckingham & 18.7 & 8.3 & 4.6 & 11.0 & 29.39 & 26.95 & 71.4 & 19.2 & 35.2 \\
\hline Suffolk & 18.4 & 10.3 & 8.0 & 11.9 & 28.99 & 26.00 & 5.9 & 32.5 & 52.3 \\
\hline Essex & 17.2 & 6.4 & 4.3 & 8.2 & 28.29 & 26.48 & 22.4 & 25.0 & 51.4 \\
\hline Bedford & 16.11 & 10.8 & 7.1 & 13.9 & 28.60 & 25.50 & 100.0 & 80.0 & 46.7 \\
\hline Oxford & 16.11 & 20.9 & 13.3 & 25.2 & 27.75 & 21.95 & 44.8 & 68.4 & 40.6 \\
\hline Northampton & 16.10 & 11.3 & 7.5 & 14.5 & 28.14 & 24.96 & 83.3 & 46.7 & 34.9 \\
\hline Wiltshire & 16.9 & 10.5 & 4.3 & 15.9 & 24.86 & 22.25 & 20.7 & 83.3 & 33.9 \\
\hline Berkshire & 15.9 & 5.6 & 3.0 & 8.1 & 28.92 & 27.30 & 12.5 & 40.7 & 42.2 \\
\hline Norfolk & 15.4 & 2.6 & 1.3 & 3.8 & 31.07 & 30.26 & 12.5 & 38.7 & 44.5 \\
\hline Huntingdon & 15.3 & 4.7 & 1.6 & 7.7 & 30.81 & 29.36 & 15.4 & 30.0 & 49.1 \\
\hline Kent & 14.5 & 6.8 & 3.2 & 9.6 & 34.61 & 32.26 & 0.0 & 31.0 & 36.0 \\
\hline Southampton & 13.10 & 7.2 & 4.2 & 10.0 & 29.04 & 26.95 & 6.9 & 65.2 & 40.7 \\
\hline Cambridge & 13.8 & 7.7 & 4.2 & 11.0 & 28.36 & 26.18 & 2.3 & 56.3 & 56.7 \\
\hline Hertford & 13.2 & 4.8 & 1.2 & 8.3 & 29.82 & 28.39 & 50.0 & 25.0 & 45.4 \\
\hline Dorset & 11.5 & 5.4 & 0.0 & 10.9 & 25.40 & 24.03 & 62.5 & 100.0 & 28.5 \\
\hline Surrey & 10.11 & 6.3 & 3.0 & 9.0 & 33.56 & 31.45 & 13.8 & 21.1 & 35.7 \\
\hline Devon & 9.0 & 4.9 & 2.6 & 6.4 & 24.55 & 23.35 & 20.8 & 70.6 & 29.5 \\
\hline Somerset & 8.10 & 3.8 & 3.7 & 3.8 & 21.27 & 20.70 & 44.0 & 68.4 & 19.2 \\
\hline Gloucester & 8.8 & 4.8 & 2.9 & 6.4 & 24.32 & 23.15 & 22.2 & 57.1 & 28.6 \\
\hline Cornwall & 6.8 & 3.0 & 1.2 & 4.7 & 22.88 & 22.19 & 16.7 & 60.0 & 31.3 \\
\hline
\end{tabular}

Source: Per capita relief expenditures, 1831 from Blaug, "The Myth of the Old Poor Law and the Making of the New," this JOURNAL, 23 (1963), pp. 178-79. Percent of agricultural land in grain production from Parliamentary Papers, Returns Relating to the Acreage of Land Under Crops, 1866, vol. 60. All others calculated by author from Parliamentary Papers, Answers to Rural Queries, 1834, vols. 30-31. 
ton, and Oxford, and almost nonexistent in Kent, Sussex, and much of East Anglia. Allotments were abundant in the Southwest, and scarce in areas close to London. Unemployment rates, as one would expect, were high in many (but not all) grain-producing counties and low in the pasture-farming Southwest. Winter unemployment rates tended to be significantly higher than summer unemployment rates. Both per capita relief expenditures and the annual earnings of agricultural laborers declined as one moved further from London; the labor market in southern England was well integrated by 1832 .

\section{ESTIMATION OF THE THREE-EQUATION MODEL}

The model to be estimated consists of three equations, to explain cross-parish variations in per capita relief expenditures, annual income of agricultural laborers, and annual unemployment rates. Two specifications of the model are estimated. The first is a three-equation reduced form. The specification of a reduced form model is based on the supposition that labor-hiring farmers dominated local parish politics, and thus were able to choose relief expenditures, wage income, and the level of unemployment to maximize profits. Estimates obtained from the reduced form yield predictions of how economic and demographic conditions affected farmers' choices.

The model regresses relief per capita, laborers' annual wage income, and annual unemployment on all the allegedly exogenous variables, Industry through Wealth, in Table 2. The expected impact of each exogenous variable is given in column 1 of Table 3.

The reduced form model does not test the hypothesis of contemporary observers that the long-term increase in per capita relief expenditures was a result of interactions among relief expenditures, wage rates, layoffs, and voluntary unemployment. Ideally, a three-equation simultaneous system should be estimated, in which wage income and the unemployment rate are assumed to be determinants of per capita relief expenditures, but also to be determined in part by the level of relief expenditures. Unfortunately, because per capita relief expenditure is in fact generosity of relief times incidence, and incidence of relief is obviously correlated with the unemployment rate, it is not possible to determine the effect of relief generosity on unemployment. Per capita relief expenditures could have a positive impact on the rate of unemployment even if generosity of relief had no effect on unemployment.

The hypothesis that relief expenditures and laborers' wage income were interrelated was tested by estimating the determinants of relief and wage income as a simultaneous system. The specific form of the model is:

$$
\begin{aligned}
\text { Relief }= & b_{Q}+b_{x} \text { Industry }+b_{2} \text { Allotments }+b_{3} \text { London }+b_{4} \text { Farmers } \\
& +b_{5} \text { Wealth }+b_{6} \text { Workhouse }+b_{7} \text { Unemployment } \\
& +b \$ \text { Income }
\end{aligned}
$$


TABLE 2

\section{THE PARISH VARIABLES FROM THE 1832 SURVEY}

Relief per capita relief expenditures of parish

Income $\quad$ expected annual income of adult male agricultural laborers

Unemployment annual unemployment rate

Industry dummy variable equal to 1 if cottage industry exists in the parish

Allotments dummy variable equal to 1 if laborers have allotments of farm land

London

Farmers

Workhouse

Childallow

Subsidy

Rate

Roundsmen

Grain

distance from London

ratio of labor-hiring farmers to total number of parish taxpayers

dummy variable equal to 1 if parish has a workhouse

dummy variable equal to 1 if parish pays children allowances

dummy variable equal to 1 if parish subsidizes wage rates of privately employed laborers

dummy variable equal to 1 if parish uses a labor rate

dummy variable equal to 1 if parish uses a roundsmen system

estimated percent of parish's adult males employed in grain production

Density

Wealth

density of population in parish

per capita value of real property in parish

Source: See Appendix.

$$
\begin{aligned}
\text { Income }- & a_{0}+a \backslash \text { Industry }+a_{2} \text { Allotments }+a_{3} \text { London } \\
& +a_{4} \text { Childallow }+a_{5} \text { Subsidy }+a_{6} \text { Rate }+a_{7} \text { Roundsmen } \\
& +a \$ \text { Density }+a_{9} \text { Relief }
\end{aligned}
$$

The expected impact of each explanatory variable is given in Table 4 .

The reasoning behind the expectations given in Tables 3 and 4 should be briefly noted. Per capita relief expenditures are expected to be determined, first of all, by the existence and magnitude of alternative income sources, namely employment opportunities in cottage industry,

TABLE 3

EXPECTED AND ACTUAL IMPACT OF EXPLANATORY VARIABLES: REDUCED FORM MODEL SUMMARY TABLE

\begin{tabular}{lcccccc}
\hline & $\begin{array}{c}\text { Dependent Variable } \\
\text { Per Capita Relief } \\
\text { Expenditures }\end{array}$ & \multicolumn{2}{c}{$\begin{array}{c}\text { Dependent Variable } \\
\text { Annual Male } \\
\text { Income }\end{array}$} & $\begin{array}{c}\text { Dependent Variable } \\
\text { Unemployment } \\
\text { Rate }\end{array}$ \\
\cline { 2 - 7 } & Expected & Actual & Expected & Actual & Expected & Actual \\
\hline Industry & - & 0 & - & - & + & 0 \\
Allotments & - & 0 & - & - & + & + \\
London & - & - & - & - & + & - \\
Farmers & + & + & - & 0 & + & + \\
Density & + & 0 & - & - & + & 0 \\
Childallow & + & + & - & - & + & + \\
Subsidy & + & 0 & - & 0 & + & 0 \\
Workhouse & + & 0 & 7 & 0 & - & 0 \\
Roundsmen & + & 0 & - & 0 & 9 & + \\
Rate & + & 0 & - & 0 & - & 0 \\
Grain & + & + & - & 0 & + & f \\
Wealth & + & 0 & + & 0 & - & - \\
\hline
\end{tabular}

Source: See text. 
TABLE 4

\section{EXPECTED AND ACTUAL IMPACT OF EXPLANATORY VARIABLES: SIMULTANEOUS EQUATIONS MODEL SUMMARY TABLE}

\author{
Dependent Variable Per \\ Capita Relief Expenditures
}

Expected Actual
Dependent Variable Annual Male Income

Expected Actual

\begin{tabular}{lc}
\hline Industry & - \\
Allotments & - \\
London & - \\
Farmers & + \\
Density & 0 \\
Childallow & 0 \\
Subsidy & 0 \\
Workhouse & + \\
Roundsmen & 0 \\
Rate & 0 \\
Grain & 0 \\
Wealth & + \\
Unemployment & + \\
Income & - \\
Relief & \\
\hline
\end{tabular}

Source: See text.

the existence of allotments, and the expected wage income of agricultural laborers. Distance from London is a proxy for cost of migration. ${ }^{24}$ As the cost of migration increased, the cost of securing an adequate peak season labor force declined, which should have caused a reduction in relief expenditures. ${ }^{25}$ The variable Farmers tests whether, as the

${ }^{24}$ By using distance from London as a proxy for the cost of migration, I am assuming that London was the destination for all potential migrants from the agricultural South. The assumption may be incorrect for rural areas close to other southern cities. During the period 1801-1831, the combined populations of Bath, Brighton, Bristol, Norwich, Plymouth, Portsmouth, and Southampton increased by 174,000 . However, over the same period, the population of London increased by 790,000 (B. R. Mitchell and P. Deane, Abstract of British Historical Statistics [Cambridge, 1962], pp. 19, 24-27). Deane and Cole found that all southern counties outside the London area experienced net out-migration from 1801 to 1831 , while London experienced heavy in-migration (P. Deane and W. A. Cole, British Economic Growth, 1688-1959 [2nd ed., Cambridge, 1967], p. 115). Thus, the attraction of, say, Bristol was not strong enough to keep Gloucester from losing workers to London. Moreover, Redford, Pollard, and Hunt agree that there was very little migration from the rural South to the industrial cities of the Northwest during this period. This suggests that London was indeed the major destination of southern migrants. Hunt concludes that "a large part of the southern labor force appears to have operated in a particularly restricted market. They moved overwhelmingly in one direction-towards London" (E. H. Hunt, Regional Wage Variations in Britain 1850-1914 [Oxford, 1973], pp. 281-84). See also Arthur Redford, Labour Migration in England, 1800-1850 (2nd ed., New York, 1968); Sidney Pollard, "Labour in Great Britain," in Peter Mathias and M. M. Postan, eds., Cambridge Economic History of Europe, (Cambridge, 1978), vol. 7, part 1.

${ }^{25}$ A negative correlation between distance from London and relief expenditures or wage income might be explained by regional differences in the cost of living rather than by my hypothesized costof-migration effect. In other words, real wage income and per capita relief expenditures might not have varied inversely with distance from London even though nominal wage income and relief expenditures did. Unfortunately, there is little available data with which to test this hypothesis. The only attempt to measure regional variations in the cost of living has been by N.F.R. Crafts for 
political power of labor-hiring farmers (estimated by the ratio of laborhiring farmers to total taxpayers) increased, they were able to pass more of the cost of maintaining their workers on to the parish. A parish's per capita property wealth might be a determinant of its relief generosity, and thus is expected to have a positive impact on relief expenditures. The variable Grain is a proxy for seasonality in the demand for labor. An increase in seasonality should have increased the winter unemployment rate and, therefore, per capita relief expenditures. The rate of unemployment is included as an explanatory variable in the simultaneous equations model, and Grain is omitted. ${ }^{26}$ Finally, Workhouse is included to test the contention, often heard before Parliamentary committees, that indoor relief was more expensive than outdoor relief. ${ }^{27}$

Equation (2) tests the extent to which alternative sources of income, various forms of outdoor relief, distance from urban labor markets, and surplus labor affected expected annual income. The variables Industry and Allotments were included to determine whether labor-hiring farmers responded to the existence of alternative (non-relief) sources of family income by reducing wage rates. Per capita relief expenditure was included in the simultaneous equations model to test whether poor relief was a substitute for wage income. The cost-of-migration hypothesis suggests that wage income should be negatively related to distance from London. Population density is a crude proxy for the relative tightness of the labor market, and thus is expected to be negatively related to wage income.

The remaining four variables represent specific forms of outdoor relief, each of which is expected to have a negative impact on wage income. The existence of child allowances for laborers with large families should have enabled farmers to reduce their wage payments to a level just high enough to support a family of three or four. Payment of wages "out of the rates," labor rates, and roundsmen systems all

the year 1843. He found that although the cost of living was indeed higher in London than in the rural South, there was no evidence of an inverse relationship between cost of living and distance from London. One can question this result, since Crafts assumes that rural rents were equal throughout England (see N.F.R. Crafts, "Regional Price Variations in England in 1843: An Aspect of the Standard-of-Living Debate," Explorations in Economic History, 19 (1982), pp. 51-70, especially pp. 62, 61). However, this assumption is supported by evidence cited in Hunt (Regional Wage Variations, pp. 79-80). In order to take account of the regional cost-of-living differences found by Crafts, I deflated nominal wage income and per capita relief expenditures using his indices.

${ }^{26}$ Grain is omitted because it should affect relief expenditures only through its impact on the unemployment rate.

${ }^{27}$ Of course, the recipients of poor relief included widows and old, sick, or infirm persons as well as able-bodied laborers and their families. Thus, cross-parish variations in per capita relief expenditures could be caused in part by differences in the proportion of widows and so forth in the parishes' populations. Unfortunately, lack of data made it impossible to control for such differences. 
involved parish subsidization of farmers who employed laborers, and thus should have caused market wage rates to decline. ${ }^{28}$

A parish's unemployment rate should be determined by its crop mix, the relative tightness of its local labor market, its relief policies, and the availability of alternative income sources. The more a parish specialized in the production of grain the higher its unemployment rate should have been, because of the highly seasonal nature of labor requirements in grain production. Density is expected to have a positive impact on unemployment.

The existence of a workhouse enabled parishes to threaten unemployed workers with indoor relief, and thus should have reduced voluntary (and total) unemployment. Payment of allowances-in-aid-ofwages (the so-called Speenhamland system) might have created serious work disincentive effects; the variable Subsidy tests whether Speenhamland policies caused an increase in the rate of unemployment. The political power of labor-hiring farmers is expected to have a positive impact on seasonal layoffs and thus on the unemployment rate. The existence of alternative income sources in the form of cottage industry and allotments might have increased the willingness of farmers to lay off workers during slack seasons. ${ }^{29}$ Both labor rates and roundsmen systems reduced the cost of employing workers during the winter months, and therefore should have a negative impact on unemployment rates. But the administration of roundsmen systems often encouraged farmers to increase layoffs in order to rehire the same workers at reduced wage costs. By some definitions of unemployment in the Rural Queries the unemployment rates might have increased under the roundsmen system.

\section{REGRESSION RESULTS}

The results are given in Tables 5 and 6 and summarized in Tables 3 and 4 . The existence of cottage industry and allotments had an impact

\footnotetext{
${ }^{28}$ The payment of poor relief to privately employed laborers occurred under the allowance system, which guaranteed laborers (whether employed or unemployed) a minimum weeky income, determined by their family size and the price of bread. The roundsmen system and the labor rate were methods for dealing with seasonal unemployment. Under the roundsmen system, seasonally unemployed laborers were offered to farmers at reduced wage rates, with the parish making up the difference between the laborers' wage income and subsistence. Under the labor rate, the parish's total wage bill for the slack season was computed, and divided among the rate-payers according to their poor rate assessment. A rate-payer could pay his share either by hiring laborers at the wage rate set by the parish or by paying the amount to the parish as a poor rate. For more details on these methods of outdoor relief, see McCloskey, "New Perspectives," pp. 430-36; and G. R. Boyer, "The Economic Role of the English Poor Law circa 1780-1834" (Ph.D. diss., University of Wisconsin, 1982), pp. 34-56.

${ }^{29}$ Alternatively, agricultural laborers might have voluntarily reduced their labor supply in response to the existence of cottage industry or allotments. See footnote 31.
} 
TABLE 5

REGRESSION RESULTS: REDUCED FORM MODEL

Dependent Variable Per Capita Relief

\begin{tabular}{|c|c|c|c|c|c|c|c|c|c|}
\hline & \multicolumn{3}{|c|}{ Expenditures } & \multicolumn{2}{|c|}{ Dependent Variable Annuc } & Iale Income & \multicolumn{3}{|c|}{ Dependent Variable Unemployment Rate } \\
\hline & $\boldsymbol{P}$ & f-Statistic & Prob $>$ in & $a$ & f-Statistic & Prob > III & $y$ & r-Statistic & Prob > \\
\hline Constant & 11.33 & 5.17 & 0.0001 & 35.45 & 26.44 & 0.0001 & 0.98 & 0.43 & 0.664 \\
\hline Industry & -1.40 & 1.52 & 0.130 & -2.58 & 4.58 & 0.0001 & 1.13 & 1.18 & 0.238 \\
\hline Allotments & -0.16 & 0.21 & 0.833 & -0.90 & 1.91 & 0.056 & 2.06 & 2.58 & 0.010 \\
\hline London & -0.04 & 4.17 & 0.0001 & -0.06 & 9.70 & 0.0001 & -0.02 & 1.77 & 0.078 \\
\hline Farmers & 5.18 & 2.42 & 0.016 & 2.08 & 1.58 & 0.114 & 4.04 & 1.82 & 0.069 \\
\hline Wealth & -0.30 & 1.64 & 0.102 & 0.05 & 0.47 & 0.640 & -0.47 & 2.52 & 0.012 \\
\hline Density & -0.49 & 0.99 & 0.322 & -0.60 & 1.98 & 0.049 & 0.41 & 0.79 & 0.428 \\
\hline Childallow & 5.18 & 5.10 & 0.0001 & -1.28 & 2.06 & 0.040 & 2.55 & 2.43 & 0.016 \\
\hline Subsidy & 0.33 & 0.34 & 0.735 & -0.46 & 0.76 & 0.445 & 1.56 & 1.54 & 0.124 \\
\hline Grain & 0.21 & 3.46 & 0.001 & -0.05 & 1.31 & 0.192 & 0.19 & 2.98 & 0.003 \\
\hline Workhouse & 1.23 & 1.44 & 0.151 & 0.77 & 1.48 & 0.139 & 0.92 & 1.04 & 0.299 \\
\hline Roundsmen & 1.14 & 0.95 & 0.342 & 0.41 & 0.57 & 0.571 & 2.18 & 1.77 & 0.078 \\
\hline Rate & 0.31 & 0.93 & 0.355 & 0.11 & 0.55 & 0.582 & 0.06 & 0.18 & 0.854 \\
\hline$R^{2}$ & 0.297 & & & 0.343 & & & 0.151 & & \\
\hline $\mathbf{N}$ & 329 & & & 329 & & & 329 & & \\
\hline
\end{tabular}

Source: See text. 
TABLE 6

REGRESSION RESULTS: SIMULTANEOUS EQUATIONS MODEL

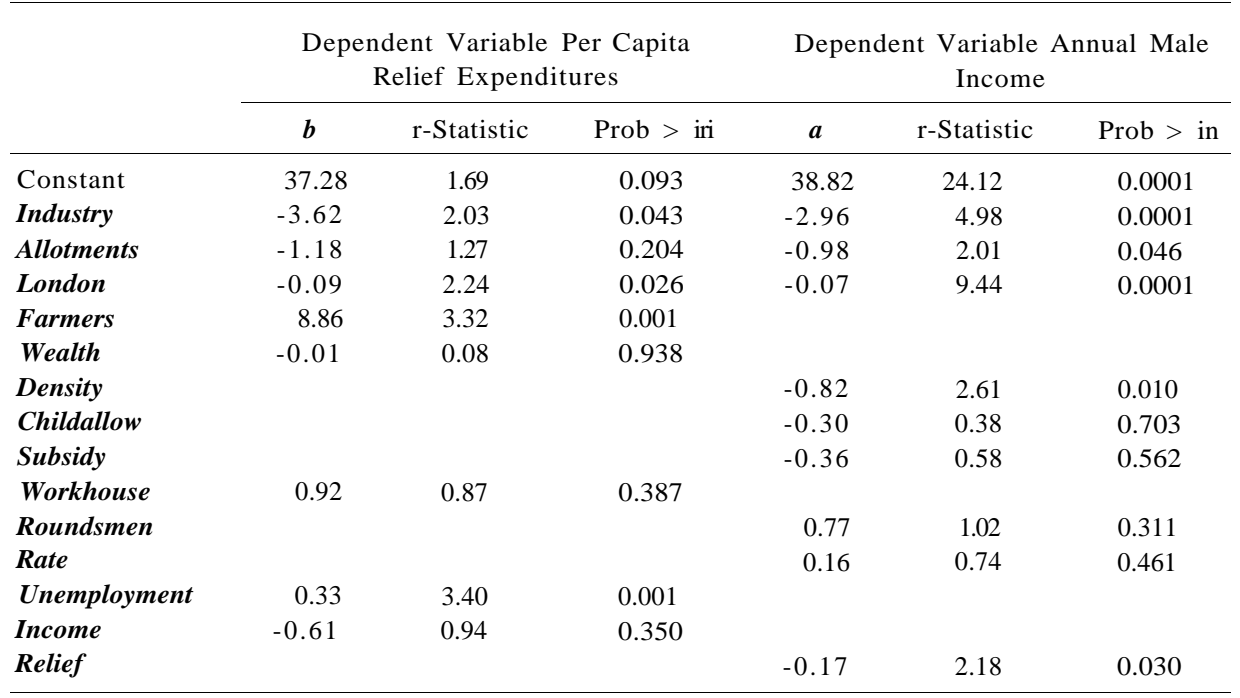

Source: See text.

on agricultural labor markets, though not necessarily the impact predicted by Eden and Davies. Employment opportunities for women and children in cottage industry did indeed cause a reduction in relief expenditures in the simultaneous equations model, but not in the reduced form. Allotments did not have an impact on relief expenditures in either model ${ }^{30}$ On the other hand, agricultural laborers' annual wage income was reduced by the existence of these alternative sources of income in both models. On average, laborers' annual income was £2.5 to £3.0 lower in parishes with employment opportunities in cottage industry than in parishes without cottage industry. The existence of allotments caused a reduction of $£ 0.9$ to $£ 1.0$ in laborers' income, other things equal. Unemployment rates were higher in parishes with allotments, suggesting that farmers increased their use of layoffs where laborers' families had other sources of income. ${ }^{31}$ Together these results

\footnotetext{
${ }^{30}$ One possible reason for this result is that the average allotment was simply too small to have a noticeable impact on relief expenditures. This hypothesis is supported by the responses to question 20 of the Rural Queries. In over 80 percent of the parishes in which laborers rented allotments, the typical allotment size was smaller than a quarter acre, the minimum size recommended by most contemporary proponents of allotment schemes. See Barnett, "Allotments," p. 175.

${ }^{31}$ As mentioned above, there is another possible interpretation for the positive impact of cottage industry and allotments on the unemployment rate. Alternative sources of income might have caused agricultural laborers to voluntarily reduce their labor supply. We can distinguish between these two hypotheses by determining the effect of cottage industry and allotments on weekly wage rates. A reduction in labor supply in response to other sources of income should have caused agricultural wage rates to increase. However, estimation of both models using agricultural laborers' summer wage rates instead of annual earnings yields the opposite result; weekly wage rates were lower in parishes containing cottage industry and allotments, other things equal. This result supports my hypothesis that labor-hiring farmers increased seasonal layoffs in response to alternative sources of income for laborers' families.
} 
offer strong support for the hypothesis that politically dominant farmers made use of cottage industry and allotments to reduce their wage bill.

Distance from London had a negative impact on agricultural laborers' earnings and on per capita relief expenditures in both models. A 10 percent increase in distance from London resulted in a 3.2 percent reduction in relief expenditures and a 1.5 percent reduction in wage income. Specialization in grain had a positive impact on both the rate of unemployment and per capita relief expenditure in the reduced form model. Moreover, the elasticities associated with specialization in grain are quite large. A 10 percent increase in the proportion of land devoted to grain implied a 5.1 percent increase in the unemployment rate and a 2.4 percent increase in relief expenditures. In the simultaneous equations model the elasticity of relief expenditures with respect to the unemployment rate is .14 . The provision of unemployment insurance was indeed a major purpose of outdoor relief and the unemployment rate was determined, in part, by crop mix.

Per capita relief expenditures and the rate of unemployment were affected by the political power of labor-hiring farmers. A 10 percent increase in the proportion of parish taxpayers who were labor-hiring farmers resulted in a 2 percent increase in the unemployment rate, and a 1.8 percent increase in per capita relief expenditures. It would appear that labor-hiring farmers did indeed use their political power to increase their subsidization by other local taxpayers.

Evidence on the notion that relief expenditures and agricultural laborers' wage income were interrelated is mixed. Per capita relief expenditures had a negative impact on laborers' annual earnings, but the effect was quantitatively small. A 10 percent increase in relief expenditures resulted in a 1.0 percent decrease in annual earnings. The existence of child allowances had a significant negative impact on laborers' earnings in the reduced form model. ${ }^{32}$ On average, agricultural laborers in parishes granting child allowances received an annual wage income $£ 1.2$ below that of laborers in parishes without child allowances. ${ }^{33}$ The above results suggest that, to some extent, the Poor Laws did indeed "create the poor which they maintain." On the other hand, the annual earnings of agricultural laborers had no impact on per capita relief expenditures. Thus, the widely accepted hypothesis that outdoor relief was used to supplement "substandard" wage income is not supported by the data.

${ }^{32}$ Child allowances also had a significant positive impact on per capita relief expenditures in the reduced form model. Parishes that granted relief to laborers "on account of their families" spent on average 5.2s. more per capita on relief than parishes without child allowances, other things equal. The mean level of per capita relief expenditures for the sample was 18.1s.

${ }^{33}$ The mean expected annual income for our sample of parishes was $£ 29.7$. None of the other three specific forms of outdoor relief (namely, the payment of wages out of the rates, roundsman system, labor rate) had a significant impact on either wage income or per capita relief expenditures. 
Finally, there is little support for the hypothesis that outdoor relief caused an increase in voluntary unemployment. The payment of allowances-in-aid-of-wages had a positive impact on the unemployment rate, but its coefficient was not significantly different from zero at the 10 percent confidence level. The existence of workhouses had a positive, though insignificant, impact on unemployment. Thus, while it was not possible to directly estimate the effect of relief generosity on unemployment, the above results provide tentative support for the revisionist hypothesis that rural parishes were selective in their granting of relief to able-bodied laborers.

\section{IMPLICATIONS FOR THE LONG-TERM INCREASE IN RELIEF EXPENDITURES}

The evidence offers little support for the Royal Poor Law Commission's hypothesis that regional variations in per capita relief expenditures were caused simply by "the abuses of the Poor Laws" by parishes in southeastern England. Conversely, several revisionist hypotheses are confirmed. Crop mix, income from cottage industry, and the political power of labor-hiring farmers were all important determinants of per capita relief expenditures. Surprisingly, the hypothesis that poor relief was used to supplement "substandard" wages was not supported by the data. Arthur Young's observation that agricultural wage rates varied inversely with distance from London was found to hold. Per capita relief expenditures also varied inversely with distance from London. Together, the results support my hypothesis that farmers anxious to secure an adequate peak season labor force were able to reduce the utility value of their workers' implicit labor contracts as the cost of migration to London increased.

What insights do the above results yield concerning the rapid increase in per capita relief expenditures after 1750? For one thing, they enable us to reject the contemporary notion that the increase in relief expenditures was caused almost exclusively by the lax administration of outdoor relief, and its effects on wage rates, laborers' productivity, and voluntary unemployment. The results also appear to reject the notion that relief expenditures increased in response to a sharp decline in laborers' landholdings. But the insignificant impact of allotments on relief expenditures in the cross-sectional regressions might simply be evidence that the average size of allotments in 1832 was small. Unfortunately there is no way to determine the extent to which laborers' allotments declined in size after 1760.

On the positive side, the regression results offer support for several new arguments and suggest promising lines of inquiry. Long-term changes in crop mix, employment opportunities or wage rates in cottage industry, the local political power of labor-hiring farmers, urban wage 
rates, or cost of migration to London could have caused relief expenditures to increase.

Parishes in the Southeast of England responded to the long-term rise in grain prices from 1760 to 1815 by increasing their specialization in grain production. ${ }^{34}$ Because of the highly seasonal labor demands of grain production, the change in crop mix must have exacerbated the problem of seasonal unemployment. Snell found that the seasonal distribution of male unemployment became more pronounced over the period. $^{35}$

Employment opportunities for women and children in cottage industry declined throughout most of southern England during the late eighteenth and early nineteenth centuries. ${ }^{36}$ Results of the crosssectional regressions show that per capita relief expenditures were reduced by up to 20 percent by the existence of cottage industry. However, the coefficient for Industry obtained from the 1832 regression understates the impact of the decline in cottage industry on the longterm increase in relief expenditures, because wage rates in cottage industry were lower in 1832 than in the late eighteenth century. ${ }^{37}$ The results suggest that the long-term decline in employment opportunities and wage rates in cottage industry reduced the annual income of many rural families by enough to force them to apply for poor relief in order to subsist.

The power of farmers increased in southern parishes after 1760 as a result of changes in the economic and legal environment. The "longterm . . . consolidation of farms into larger and more efficient units" that had begun in the seventeenth century was encouraged by the wave of enclosures between 1760 and $1815^{38}$ The decline in the number of smallholders increased the power of labor-hiring farmers. The passage of Gilbert's Act (1782) introduced "the principle of weighting the right to vote according to the amount of property occupied." The principle was extended by the 1818 Parish Vestry Act, which allowed rate-payers up to six votes in vestry, depending on their poor rate assessment. ${ }^{39}$ Because farmers were generally the largest property holders in rural parishes their political power was significantly increased in parishes that

** K. D. M. Snell, "Agricultural Seasonal Unemployment, the Standard of Living, and Women's Work in the South and East, 1690-1860," Economic History Review, 2nd ser., 34 (1981), pp. 40737.

35 Ibid., p. 411.

${ }^{36}$ Boyer, "An Economic Model," pp. 140-42.

${ }^{37}$ Evidence that wage rates in cottage industry had been declining for some time prior to 1832 can be found throughout the Rural Queries (Parliamentary Papers, 1834, vol. 30, pp. 7, 31, 41, 178, $217,226,332,334,340,369,372,409,582)$. For a discussion of the long-term decline in wage rates and employment opportunities, see Ivy Pinchbeck, Women Workers and the Industrial Revolution, 1750-1850 (reprint, London, 1981), pp. 138-45, 208, 220-21, 225. 92.

${ }^{38}$ J. D. Chambers and G. Mingay, The Agricultural Revolution, 1750-1880 (London, 1966), p.

${ }^{39}$ A. Brundage, The Making of the New Poor Law (New Brunswick, N.J., 1978), pp. 7, 10. 
adopted either of these acts. The cross-sectional evidence suggests that farmers used their power to pass some of their labor costs on to nonlabor-hiring ratepayers.

Wage rates for unskilled laborers in London increased more rapidly than agricultural wage rates in southern England from the 1770s to the 1830 s. ${ }^{40}$ The conclusion here that the southern labor market was well integrated in the early nineteenth century suggests that the relative increase in London wage rates forced farmers to increase relief expenditures to maintain a resident labor force.

\section{CONCLUDING REMARKS}

Changes in economic and political factors appear to have been a major cause of the rapid increase in relief expenditures from 1750 to 1834. The results offer strong support for the revisionist analysis of the economic role of the Old Poor Law begun by Blaug, or indeed Polanyi. They contrast sharply with the analysis contained in the 1834 Report of the Royal Poor Law Commission. This is ironic, since the data used here is the Commission's own. The Commissioners neglected the returns because they had already concluded that the administration of outdoor relief was to blame for the long-term increase in relief expenditures. ${ }^{41}$ The upshot was unfortunate, since their Report continues to influence attitudes towards social welfare.

\section{Appendix}

The sources of the data utilized in the empirical analysis are listed below. Shortened names of variables are in parentheses.

Per Capita Relief Expenditures (Relief). Relief expenditures in 1831 (measured in shillings) divided by population in 1831. All data obtained from the Rural Queries.

Unemployment Rate (Unemployment). Data on unemployment obtained from Question 6 of the Rural Queries: "Number of Labourers generally out of employment, and how maintained in summer and winter?" The unemployment rate was constructed by taking a simple average of the summer and winter unemployment levels (assuming the winter unemployment level to be relevant for one-half of the year and the summer unemployment level for one-half) and dividing by an estimate of the total number of wage laborers in the parish. The latter was assumed to consist of the number of agricultural laborers, nonagricultural laborers, and adult males employed in handicrafts and retail trade, as given in the 1831 Census.

${ }^{40}$ A. L. Bowley, Wages in the United Kingdom in the Nineteenth Century (Cambridge, 1900), pp. 81-83, table at end of book.

${ }^{41}$ Sidney Webb and Beatrice Webb maintained that the Commission's "investigation [of the Poor Law] was far from being impartially or judicially directed and carried out"; see English Local Government: English Poor Law History: The Last Hundred Years (London, 1929), pp. 85-86. The hypothesis would appear to be supported by the 1834 Report's selective use of information from the Rural Queries. 
Laborers' Annual Wage Income (Income). Data obtained from the Rural Queries, Questions 8 (weekly wages for adult males), and 10 (annual income for adult males). Problems arose because Question 10 had a relatively low response rate. Fortunately, the response rate to Question 8 was nearly 100 percent. I constructed estimates of annual wage income for those parishes that did not answer Question 10 in the following way.

First, the data was divided up by counties. Second, for those parishes in each county which had data on male summer wage rates, winter wage rates, and annual earnings, $Y y$, an estimate of annual income, Z,y, was constructed:

$$
Z n=26 W_{S}+26 W_{W}
$$

where: $W_{s}=$ summer wage

$$
\begin{aligned}
W_{w} & =\text { winter wage } \\
i & =\text { parish, } i=1, \mathrm{n} \quad \mathrm{n}=\text { number of parishes in county } \\
j & =\text { county }, j=1,21
\end{aligned}
$$

A ratio $R y$ was then defined as

$$
R_{0}=Z y / Y i j
$$

Each county's ratio was thus

$$
R j=\text { liRiJn }
$$

Third, each county's ratio, $R_{j 9}$ was used to construct estimates of annual earnings, $Y_{U t}$ for those parishes that reported wage rates but not earnings data.

$$
Y_{0}=\left[26 W_{S i j}+26 W_{W i}\right) / R j \text { or } Y_{u}=Z r f R j
$$

The calculated $R j$ for each county was approximately equal to 1.0. This suggests that neither harvest wages nor unemployment probabilities were taken into account in the estimates of male income given by parish overseers in Question 10.

Cottage Industry (Industry). Dummy variable equal to 1 if some form of cottage industry existed in the parish. Information on the existence of cottage industry obtained from Question 11 of the Rural Queries: "Have you any and what Employment for Women and Children?"

Allotments: Dummy variable equal to 1 if laborers rented land on which to grow food. Information on the existence of allotments obtained from Question 20 of the Rural Queries: "Whether any land let to labourers; if so, the Quantity to each, and at what Rent?"

Distance from London (London): Distance from the center of each county to London. Distance was measured at the county level because of the difficulty of locating individual parishes within counties.

Political Power of Labor-Hiring Farmers (Farmers): The variable measures the percentage of parish rate-payers who were labor-hiring farmers. The number of laborhiring farmers is given in the 1831 Census. The number of parish rate-payers was estimated by assuming that all adult males not designated by the 1831 Census as agricultural laborers, nonagricultural laborers, or persons employed in handicrafts or retail trade owned enough property to be taxed.

Density: Density is measured as population per acre. Population data was obtained from the Rural Queries. Data on parish acreage was obtained from the 1831 Census.

Child Allowances, Employed Laborers Receiving Relief(Childallow, Subsidy): Childallow is a dummy variable equal to 1 if the parish had a system of child allowances. Subsidy is a dummy variable equal to 1 if laborers received relief payments while privately employed. Information on the existence of both practices was obtained from Question 24 of the Rural Queries: "Have you any, and how many, able-bodied labourers in the employment of individuals receiving allowance or regular relief from your parish on their own account, or on that of their families?" 
Specialization in Grain Production (Grain): An estimate of the extent of grain production in the parish was obtained by calculating the percentage of a parish's adult males who were employed in agriculture (using data from the 1831 Census) and multiplying this figure by the relevant county's "percentage of corn crops to total acreage under all kinds of crops, bare fallow, and grass." Data on crop mix were obtained at the county level for 1866, the earliest year for which data were available, from Parliamentary Papers, Returns Relating to the Acreage of Land Under Crops, vol. 60, 1866.

Workhouse: Dummy variable equal to 1 if the parish contained a workhouse. Data obtained from Question 22 of the Rural Queries: "Have you a workhouse?"

Roundsmen System (Roundsmen): Dummy variable equal to 1 if the parish used a roundsmen system. Data obtained from Question 27 of the Rural Queries: "Whether the system of roundsmen is practiced, or has been practiced?"

Labor Rate (Rate): Dummy variable equal to 1 if the parish used a labor rate. Data obtained from Question 28 of the Rural Queries: "Whether laborers are apportioned amongst the occupiers according to the extent of occupation, acreage rent, or number of horses employed?"

Per Capita Property Value (Wealth): Per capita value of real property in parish. Data on real property value in 1815 obtained from Parliamentary Papers, Comparative Account of the Population of Great Britain . . . With Annual Value of Real Property, 1815, vol. 18, 1831. 